\title{
FUNGI ASSOCIATED WITH ROTTEN FRUITS IN DHAKA METROPOLIS
}

\author{
MA BASHAR*, S SHAMSI AND M HOSSAIN \\ Department of Botany, University of Dhaka, Dhaka-1000, Bangladesh
}

Key words: Fungi, Fruit rot, Dhaka metropolis

\begin{abstract}
A total of 18 species of fungi representing nine genera were found to be associated with the rotten fruits collected from the markets of Dhaka metropolis. The fungi isolated from the fruits were Alternaria alternata ( Fr.) Keissler, Alternaria sp., Aspergillus flavus Link., A. niger Van Tiegh, A. fumigatus Fresenius, A. terreus Thorn, Colletotrichum gloeosporioides (Penz.) Sacc, Colletotrichum sp.1, Colletotrichum sp.2, Curvularia brachyspora Boedijn, C. clavata Jain, Curvularia sp., Fusarium oxysporum Sch., Penicillium sp., Rhizopus nigricans Ehrenberg, Rhizopus sp., Syncephalastrum sp. and Trichoderma sp. Apergillus niger was found to be associated as the predominant fungus with the rotten fruits.
\end{abstract}

Fruits are attacked by fungi, bacteria and other agents causing different types of disease. Over 25 to 30 per cent loss of fruits are caused by fungal diseases in transit and storage. Fruits may be affected either by dry or soft rot. Soft or pulpy fruits undergo a soft or wet rot because of the abundance of water in their tissue (Defosent 1933). The common post harvest and storage fungi of fruits are Alternaria alternata, Aspergillus flavus, A. fumigatus, A. niger, Fusarium oxysporum, Geotrichum sp. Rhizopus nigricans, R. stolonifer and Penicillium spp. (Bhale 2011). Lot of research has been done on fruit rot abroad but insufficient information is available in Bangladesh (Anon. 2005). Therefore, the present investigation was undertaken to find out the association of fungi with the rotten fruits of Dhaka metropolis and to identify them.

Five economically important fruits i.e. apple (Pyrus malus L.), banana (Musa paradisiaca L.), grape (Vitis vinifer L.), litchi (Litchi chinensis L.) and mango (Mangifera indica L.) were selected for this experiment. All the fruits were collected from different markets of Dhaka metropolis. Symptoms of the rotten fruits were recorded. Local fruits like banana and mango showed more fungal association than apple, grape and litchi. The fungi associated with the infected fruits were isolated on PDA medium from the collected samples following tissue planting method (CAB 1968) at $\mathrm{pH}$ 6.0. Thirty inocula each of $2 \mathrm{sq}$. $\mathrm{mm}$ in size were prepared from each sample. The surface of which was sterilized with $10 \%$ Chlorox for 3 min. Three inocula were inoculated in each sterilized Petri plate with solidified agar medium and incubated for 5-7 days at $25-28^{\circ} \mathrm{C}$. The fungi growing out of each inoculum was examined and identified following the standard literature (Ellis 1971, 1976, Benoit and Mathur 1970, Booth 1971, Barnet and Hunter 1972, Sutton 1980). Per cent frequency of the occurrence of the fungal isolates was calculated by adopting the formula of Spurr and Welty (1972). The symptoms of different rotten fruits were recorded and presented in Fig.1.

Apple: pale brown, reddish brown and dark brown, dry, smooth spots on the infected fruits. Banana: dark brown to black, dry spots sometimes with fungal growth on fruit surface. Grape: rotten fruits were whitish, brown, black, watery, smooth or with shrinking surface skin. Litchi: brown lesion with white fungal growth on infected fruits with smooth or rough surface. Mango : infected fruits showed brown to black, dry, regular or irregular lesions with shrinking surfaces.

*Author for correspondence: <botanybashar@yahoo.com> 

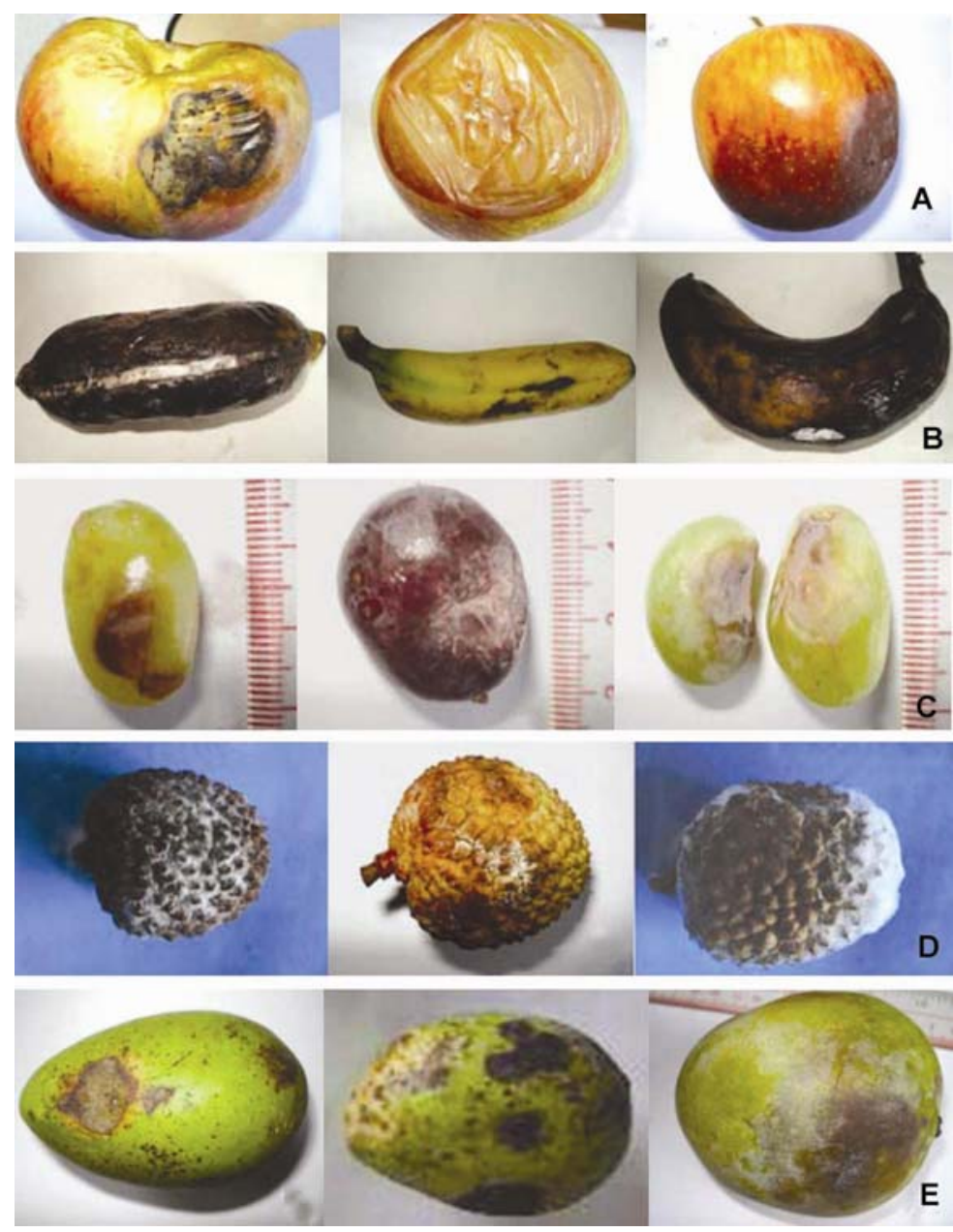

Fig. 1A-E. Symptoms of rotten fruits. A-E represent rot of apple (A), banna (B), grape (C), litchi (D) and mango (E).

A total of 18 species of fungi were isolated from 25 samples of rotten fruits. From infected apple nine fungal species representing five genera were isolated. In this fruit the frequency of association of Aspergillus niger was highest (44\%) and Curvularia sp. was lowest (1.33\%). This reveals that the species of Aspergillus were the predominating fungi in apple rot (Table 1). In banana, eleven fungal species representing eight genera were isolated from the samples examined. Frequency of association of Rhizopus nigricans was highest in it (14\%; Table 1). Five fungal species representing four genera were isolated from the samples of rotten grapes. Frequency of association of $R$. nigricans was highest (19.33\%) and lowest in A. niger (10.67\%). Rhizopus sp. was the predominating fungi associated with grape rot (Table 1). In case of litchi six fungal species representing five genera were isolated from the rotted samples. In this fruit the frequency of association of Colletotrichum sp.1 was highest (20.66\%). Eleven fungal species representing seven genera were isolated from infected fruits of mango. Frequency of association of A. niger was highest (20.00\%). Aspergillus niger was the predominating fungi in mango rot (Table 1). 
Table 1. Per cent frequency of association of fungi with rotten fruits.

\begin{tabular}{lccccccc}
\hline \multirow{2}{*}{$\begin{array}{l}\text { Name of } \\
\text { the fungi }\end{array}$} & Apple & Banana & Grape & Litchi & Mango & Total & Mean \\
\cline { 2 - 6 } & 1.33 & 5.33 & 13.33 & 4.66 & 2.00 & 26.66 & 5.12 \\
\hline Alternaria alternata & 15.67 & - & - & - & - & 15.67 & 3.13 \\
Alternaria sp. & 4.67 & 3.33 & 11.33 & 0.93 & 7.33 & 27.60 & 5.52 \\
Aspergillus flavus & 3.33 & - & - & - & 5.00 & 8.33 & 1.67 \\
A. fumigatus & 44.00 & 5.33 & 10.67 & - & 20.00 & 80.00 & 16.00 \\
A. niger & 5.00 & - & - & - & 8.67 & 13.67 & 2.73 \\
A. terreus & & & & & & & \\
Colletotrichum & - & 8.67 & - & 6.60 & - & 15.27 & 3.05 \\
gloeosporioides & - & 0.67 & - & 20.66 & - & 21.33 & 4.26 \\
Colletotrichum sp.1 & - & 0.67 & - & - & - & 0.67 & 0.13 \\
Colletotrichum sp. 2 & - & - & - & - & 2.00 & 2.00 & 0.40 \\
Curvularia brachyspora & - & 2.67 & - & - & 2.00 & 4.67 & 0.93 \\
C. clavata & 1.33 & - & - & - & - & 1.33 & 0.27 \\
Curvularia sp. & - & 1.33 & - & 20.00 & - & 21.33 & 4.27 \\
Fusarium oxysporum & - & 1.33 & - & - & 13.33 & 14.67 & 2.97 \\
Penicillium sp. & - & 14.00 & 19.33 & 0.93 & 2.00 & 36.27 & 7.25 \\
Rhizopus nigricans & 2.00 & - & - & - & - & 2.00 & 0.40 \\
Rhizopus sp. & 2.00 & - & 12.67 & - & 19.33 & 34.00 & 6.80 \\
Syncephalastrum sp. & - & 5.33 & - & - & 1.33 & 6.67 & 1.33 \\
Trichoderma sp. & & & & & &
\end{tabular}

The results of this experiment suggests that rotten fruits nourishes various types of fungi. Some of them produces mycotoxin which may cause harm to the consumers.

\section{References}

Anonymous 2005. Studies on fruit rot pathogens with special reference to Fusarium sp. Plant Pathology and Mycology Laboratory, Department of Botany , University of Rajshahi, Bangladesh. pp. 37.

Barnet HL and SB Hunter 1972. Illustrated Genera of Imperfect Fungi. 3rd Ed.. Burgess Publishing Co., USA. pp. 255 .

Bhale 2011. Survey of market storage diseases of some important fruits of Osmannabad district, India. Science Research Repoter. 1(2):88-91.

Benoit MA and SB Mathur 1970. Identification of species Curvularia on rice seed. Proc. Inst. Seed Test. Ass. 35(1): 1-23.

Booth C 1971. The Genus Fusarium. The Commonwealth Mycological Institute, England. pp. 273.

CAB (Commonwealth Agricultural Bureau) 1968. Plant Pathologist's Pocket Book. $1^{\text {st }}$ edition, The Commonwealth Mycological Institute, Kew, Surrey, England, pp.267.

Defosent F 1933. Manual of Fruit Disease. $2^{\text {nd }}$ Ed. McGraw Hill Co. ,New York.

Ellis MB 1971.Dematiaceous Hyphomycetes. Commonwealth Mycological Institute, England. pp. 508.

Ellis MB 1976. More Dematiaceous Hyphomycetes. Commonwealth Mycological Institute, England. pp. 507.

Spurr HWJ and RE Welty 1972. Incidence of tobacco leaf mycoflora in relation to brown spot disease and fungicidal treatment. Phytopathol. 62: 616-920.

Sutton BC 1980. The Coelomycetes. $1^{\text {st }}$ Ed. Commonwealth Mycological. Institute. Kew, Surrey, England. pp. 696. 